\title{
An Apollo 15 mare basalt fragment and lunar mare provinces
}

\author{
GRAHAM RYDER ${ }^{1 *}$ AND TRINA COX BURLING ${ }^{1,2}$ \\ ${ }_{1}$ Lunar and Planetary Institute, 3600 Bay Area Blvd., Houston, Texas 77058-1113, USA \\ 2Present address: Department of Geosciences, Texas Technical University, Box 41053, Lubbock. Texas 79409. USA \\ ${ }^{*}$ Correspondence author's e-mail: zryder(a)pi.jsc.nasa.gov
}

(Received 1995 May 22; accepted in revised form 1995 September 7)

\begin{abstract}
Lunar sample 15474,4 is a tiny fragment of olivine-augite vitrophyre that is a mare basalt. Although petrographically distinct from all other Apollo 15 samples, it has been ignored since its first brief description. Our new petrographic and mineral chemical data show that the olivines and pyroxenes are distinct from those in other basalts. The basalt cooled and solidified extremely rapidly; some of the olivine might be cumulate or crystallized prior to extrusion. Bulk-chemical data show that the sample is probably similar to an evolved Apollo 15 olivine-normative basalt in major elements but is distinct in its rare earth element pattern. Its chemical composition and petrography both show that 15474,4 cannot be derived from other Apollo 15 mare basalts by shallow-level crystal fractionation. It represents a distinct extrusion of magma.

Nonetheless, the chemical features that 15474,4 has in common with other Apollo 15 mare basalts, including the high $\mathrm{FeO} / \mathrm{Sc}$, the general similarity of the rare earth element pattern, and the common (and chondritic) $\mathrm{TiO}_{2} / \mathrm{Sm}$ ratio, emphasize the concept of a geochemical province at the Apollo 15 site that is distinct from basalts and provinces elsewhere. In making a consistent picture for the derivation of all of the Apollo 15 basalts, both the commonalities and the differences among the basalts must be explained. The Apollo 15 commonalities and differences suggest that the sources must have consisted of major silicate phases with the same composition but with varied amounts of a magma trapped from a contemporary magma ocean. They probably had a high olivine/pyroxene ratio and underwent small and reasonably consistent degrees of partial melting to produce the basalts. These inferences may be inconsistent with models that suggest greatly different depths of melting among basalts, primitive sources for the green glasses, or extensive olivine fractionation during ascent. An integrated approach to lunar mare provinces, of which the Apollo 15 mare basalts constitute only one, offers advances in our understanding of the physical and chemical processes of source formation and mare production but has so far not been utilized.
\end{abstract}

\section{INTRODUCTION}

The lunar mare basalt samples collected from only a few locations during the $\Lambda$ pollo and Luna missions more than 20 years ago have an extremely wide range of chemical compositions (see, e.g., Taylor, 1982; Taylor et al, 1991; Neal and Taylor, 1992). Antarctic meteorites from the lunar mare basalt terrains have expanded this range (e.g., Warren and Kallemeyn, 1993; Koeberl et al., 1993). Small variations are attributable to shallow or surface crystallization and differentiation, but large differences (such as the ranges in $\mathrm{TiO}_{2}$ from $0.5 \mathrm{wt} \%$ to $\sim 14 \mathrm{wt} \%$ and in incompatible element ratios) are not and must be attributed to the chemistries of the magmas that ascended from the interior. Simple models of the origin of these parent magmas, ranging from partial melting of a common primitive lunar interior to simple remelting of stratified cumulates that had been formed during differentiation of a primordial magma ocean, were abandoned early in favor of more complex petrogenetic models for most mare basalts (Hubbard and Minear, 1975; Ringwood and Kesson, 1976).

The more complex models almost all retain the magma ocean differentiation and its cumulates but add complexity necessary to explain the chemical characteristics of individual mare magmas (summary in Neal and Taylor, 1992). These models include mixing or hybridization of different stratigraphic levels of source cumulates by sinking pods or convective overturn before or during melting (in some cases, including primitive interior materials); trapping of ocean magma in the source cumulates; and post-melting fractional crystallization combined with assimilation. Polybaric melting and open-system crystallization have appeared necessary in at least a few cases. These processes are not mutually exclusive.
Given that only a tiny proportion of mare basalts have been sampled, it would seem most likely that the total mare diversity is even greater. Many chemical regularities or relationships so far inferred may disappear in the future as the Moon is explored (just as the early idea of a correlation of age and $\mathrm{TiO}_{2}$ group became obviously wrong). One generalization has been that low-Ti basalts are characterized by lower abundances of incompatible elements. $\mathrm{Sc}$, and $\mathrm{Sr}$ than the high-Ti basalts. However, new information on mare basalt chemical compositions indicates that such generalizations are not universal (Warren and Kallemeyn, 1993; Ryder et al. 1995). Thus, even some general consistency in petrogenetic models for low-Ti basalts might not exist.

While the complexity and multiplication of models allows the inferred chemical composition of any particular crupted basalt to have been formed in numerous possible ways, there are some regularities that promise to add constraints. The variation in chemical composition does not seem to be entirely random with eruption episode; one episode produces magmas with some clear chemical affinities to the others, even though they cannot be related by shallow level fractionations of a common magma. These affinities go beyond mere similarity in $\mathrm{TiO}_{2}$ abundance and exist even with significant $\mathrm{TiO}_{2}$ differences. Such chemical affinities in an episode, producing a geochemical province, must provide constraints on the source regions and the processes of melt production, migration, and eruption. Surprisingly, the relationships among basalts in a province have barely been used as yet to attempt to define, in both physically and chemically plausible ways, how the province and its mantle sources, rather than individual basalts, were produced (for instance, these relationships are not discussed in the 

reviews of mare magmatic cruption by Head and Wilson, 1992; or Spera, 1992).

This paper first describes a fragment of unique mare basalt from the Apollo 15 landing site. Its combination of high olivine abundance, mineral chemical composition, rock texture, and minor clement chemical composition distinguish this sample in detail from all others at the Apollo 15 landing site; it was a separate magma and cruption. Nonetheless, it has chemical features, including $\mathrm{FeO} / \mathrm{Sc}$, that are like other Apollo 15 mare basalts and not like those from other landing sites. This sample reinforces and encourages the concept of a lunar geochemical province. This paper then suggests some of the constraints that consideration of the province, rather than just single basalts in isolation, places on concepts of the mare sources and magma processes at the Apollo 15 site. An integrated approach to such provinces, of which others exist on the Moon, is ultimately more profitable than the modelling of individual basalts alone.

\section{OLIVINE-AUGITE VITROPHYRE FRAGMENT 15474,4 AND ANALYTICAL METHODS}

Sample 15470 was the only sample of regolith collected on the rim of the $460 \mathrm{~m}$ diameter Dune Crater on the mare plains at the Apollo 15 landing site. All of the six larger mare basalts collected at this location were members of the $A 15$ quartz-normative group; none were from the Apollo 15 olivine-normative basalt group. No rake sample was collected near Dune Crater. Sample 15474 is the 4 $1 \mathrm{~nm}$ to $10 \mathrm{~mm}$ fraction of the portion of the regolith sample that was sieved and consisted of only seven particles. Sample 15474,4 was the only one of them described, in a catalog by Powell (1972), as a tough, porphyritic basalt that was subangular and dark gray. The particle was a mere $0.18 \mathrm{~g}$ with a maximum length of $6 \mathrm{~mm}$. The phenocrysts were orange-yellow, anhedral, and as much as $1 \mathrm{~mm}$ long; Powell (1972) inferred (correctly) that they were olivines. Two thin sections $(, 22$ and, 23$)$ from split, 14 show the particle to be a unique olivine-augite vitrophyre (Figs. 1, 2a), particularly distinguished among $A$ pollo 15 samples by its great abundance of olivine and by its pleochroic pink "totem-pole" augite crystals that contain high abundances of alumina and titania (Powell et al, 1973). A microprobe analysis for major elements of a glass made by fusing a homogenized powdered sample also indicated that the vitrophyre was distinct in chemical composition from other mare basalt groups (Powell et al., 1973). Despite its unique characteristics, the sample has been virtually ignored, and no minor element chemical composition or radiometric age determinations have been made. It is not discussed in any of the major reviews of mare basalt petrogenesis (e.g., BVSP, 1981; Papike et al., 1976; Neal and Taylor, 1992). The sample and its splits are documented in Ryder and Sherman (1989).

To better constrain the petrogenesis of this mare basalt fragment and to assess its possible relationships with other lunar mare basalt types, we restudied the petrography and mineral chemical composition of the sample. We also determined some chemical characteristics, using standard instrumental neutron activation analysis techniques and clean room facilities at the Johnson Space Center, Ilouston, Texas. For comparison, estimates of the major element chemical composition derived from the mode and mineral chemical composition, as well as the analysis of glass from fusing powder (Powell et al, 1973) are in Table 1. For the neutron activation analysis, a $30 \mathrm{mg}$ chip $(, 15)$ was obtained and gently crushed. A small, typical chip was reserved for potential Ar-

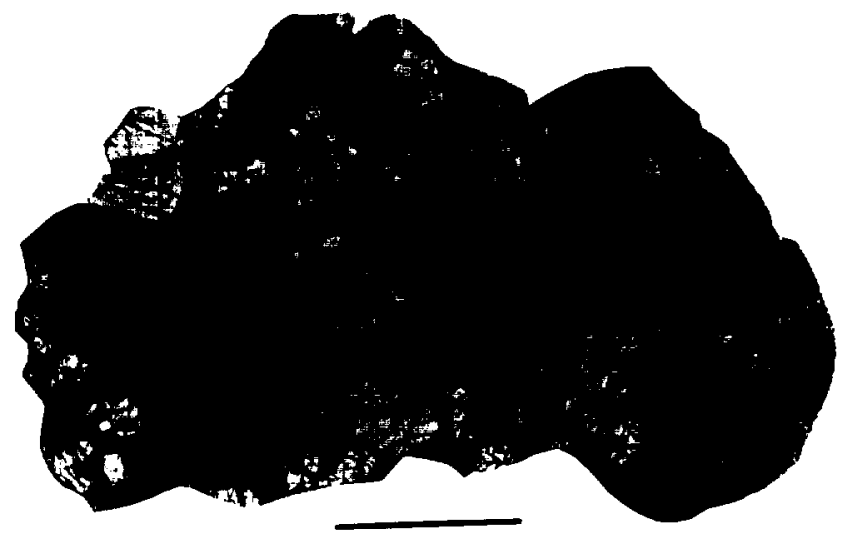

FIG. 1. Photomicrograph of entire thin section of $15474,4,14$, mounted as , 22 on 15999,96 . Plane transmitted light. Scale bar is $1 \mathrm{~mm}$. White euhedral/ subhedral crystals are olivines with dark inclusions of chromite and trapped melt; elongate "totem poles" are augites; dark material is finegrained mass of augite, pyrox ferroite, plagioclase, glass, ilmenite, and traces of Fe-metal.

Ar age determinations and the remainder further crushed to obtain separates dominated by olivine ( $2 \mathrm{mg}$ ) and by groundmass ( $15 \mathrm{mg}$ ). The data for these separates and their recombination for the bulk chemical composition are reported in Table 2 . We made separates in the hope of obtaining more detailed information on elemental relationships. However, the chemical characteristics themselves show that they were not pure, with each scparate containing $5 \%$ to $10 \%$ of the other. The olivine-rich fraction also contains $-1 \%$ chromite.

\section{PETROGRAPHY AND MINERAL CHEMICAL COMPOSITION}

We redetermined the volumetric mode of $15474,4,14,22$ counting 1500 points, finding $22.8 \%$ olivine, $32.8 \%$ augite, $1.6 \%$ oxides, and $42.8 \%$ groundmass. This mode is similar to that of Powell et al. (1973) except that we counted more Cr-spinel. The groundmass is a variolitic or radial intergrowth of augite, pyroxferroite, and plagioclase. Glass, tiny Ti-oxides, and rare submicron grains of Fe-metal are also present in the groundmass. Olivine crystallized first, and apparently alone, to be joined or succeeded by chromite and then succeeded by pyroxene before the groundmass solidified.

The olivine phenocrysts are as large as $1 \mathrm{~mm}$ across While some have borders, suggestive of some reaction and resorption, most have euhedral or subhedral boundaries. The largest is internally skeletal (Fig. 2b), but most are not. A few have dendritic projections (swallow tails) indicative of
TABLE 1. Estimates of major element composition of 1574.4 .

\begin{tabular}{|c|c|c|c|}
\hline & 1 & 2 & 3 \\
\hline $\mathrm{SiO}_{2}$ & 44.58 & 45.53 & 46.4 \\
\hline $\mathrm{TiO}_{2}$ & 2.50 & 2.45 & 2.46 \\
\hline $\mathrm{Al}_{2} \mathrm{O}_{3}$ & 9.54 & 9.98 & 8.47 \\
\hline $\mathrm{Cr}_{2} \mathrm{O}_{3}$ & 0.85 & 0.40 & 0.59 \\
\hline $\mathrm{FeO}$ & 22.16 & 21.55 & 22.1 \\
\hline $\mathrm{MnO}$ & 0.27 & 0.26 & 0.31 \\
\hline $\mathrm{MgO}$ & 9.26 & 8.87 & 9.52 \\
\hline $\mathrm{CaO}$ & 10.57 & 10.65 & 9.55 \\
\hline $\mathrm{Na}_{2} \mathrm{O}$ & 0.34 & 0.37 & $(0.01)^{*}$ \\
\hline $\mathrm{K}_{2} \mathrm{O}$ & 0.05 & 0.05 & 0.04 \\
\hline Sum & 100.12 & 100.11 & 100.13 \\
\hline $\mathrm{Mg}$ & 42.69 & 42.32 & 43.43 \\
\hline
\end{tabular}

1 = reconstructed from mode and phase chemical compositions of this study.

$2=$ reconstructed as 1 using mode of Powell et al. (1973).

$3=$ microprobe fused bead analysis of $15474,4,14,24$ by Powell el al. (1973).

* Na loss in fusing powder. 

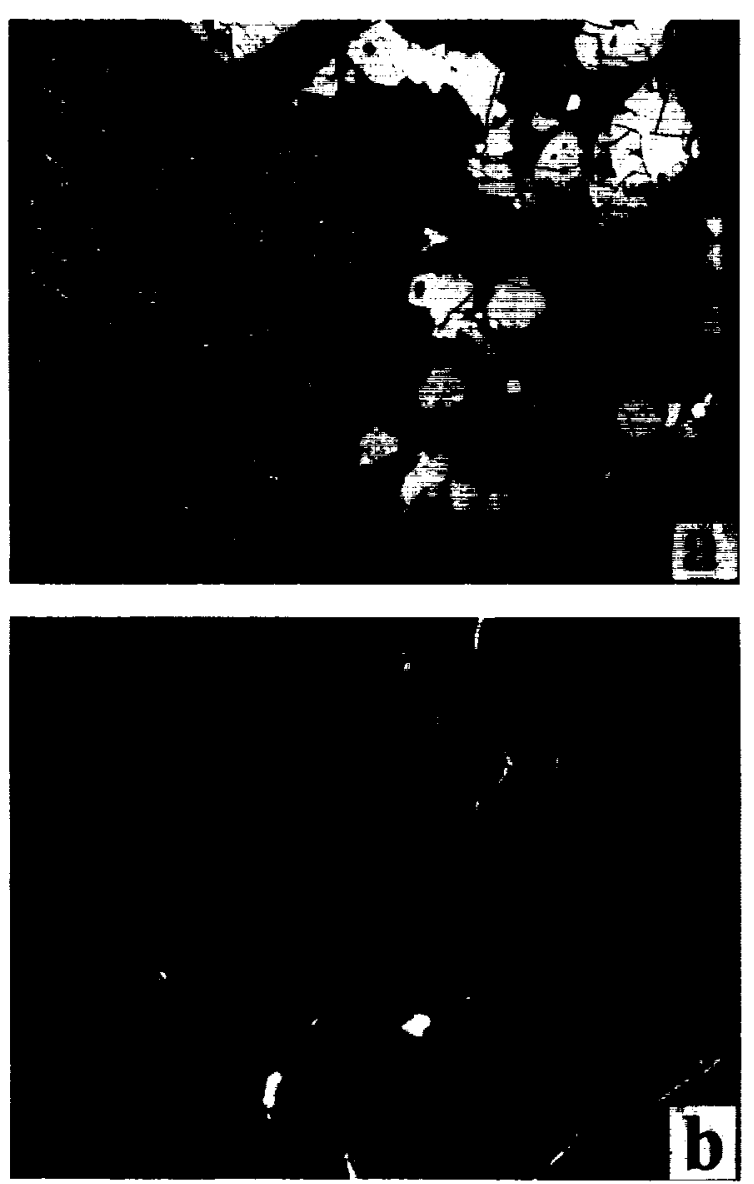

rapid cooling subsequent to phenocryst growth (Fig. 2c). The olivines are zoned normally and contain inclusions of trapped melt and of euhedral chromites that are rarely as large as $50 \mu \mathrm{m}$. In no case does olivine enclose pyroxene. We measured a greater range of olivine compositions $\left(\mathrm{Fo}_{60-35}\right)$ than did Powell et al. (1973), but the range is less than in Apollo 15 olivine-normative basalts (Fig. 3 ). The largest crystal has the most magnesian core. The grain with the most conspicuous swallow tail (Fig. 2c) is among the most Ferich olivines $\left(\mathrm{Fo}_{40}\right)$ and is surrounded by $\sim 50 \mu \mathrm{m}$ of groundmass that is depleted in opaque phases. A few other olivines also have such surroundings. There are no discontinuities in composition, suggesting (as does the habit) that the olivines crystallized continuously and are not xenocrysts. They have lower abundances of $\mathrm{CaO}$ at corresponding $\mathrm{Fo}$ contents than do olivines in most other mare basalts, including the Apollo 15 olivine-normative basalts (e.g., Fig. 3); $\mathrm{Cr}_{2} \mathrm{O}_{3}$ in olivines is similarly low. The chromites are most commonly at the boundaries of olivine grains or embedded in pyroxene adjacent to olivine; a few are in the groundmass. They contain $\sim 10 \% \mathrm{Al}_{2} \mathrm{O}_{3}$ and $9 \% \mathrm{TiO}_{2}$.

The pyroxenes are elongated, and skeletal phenocrysts are as long as $1 \mathrm{~mm}$ (Figs. 1, 2a). They tend to radiate in clusters. Some, especially rims, are intergrown with (and grade into) the groundmass; many have sieved textures from inclusions of plagioclase and pyroxferroite. The phenocrysts are high-Ca augites, zoned normally but not extensively (Fig. 4) (although we did not attempt to analyze thin $\mathrm{Fe}$-rich rims or groundmass augite in this study). Pink and mildly pleochroic, they have unusually high alumina

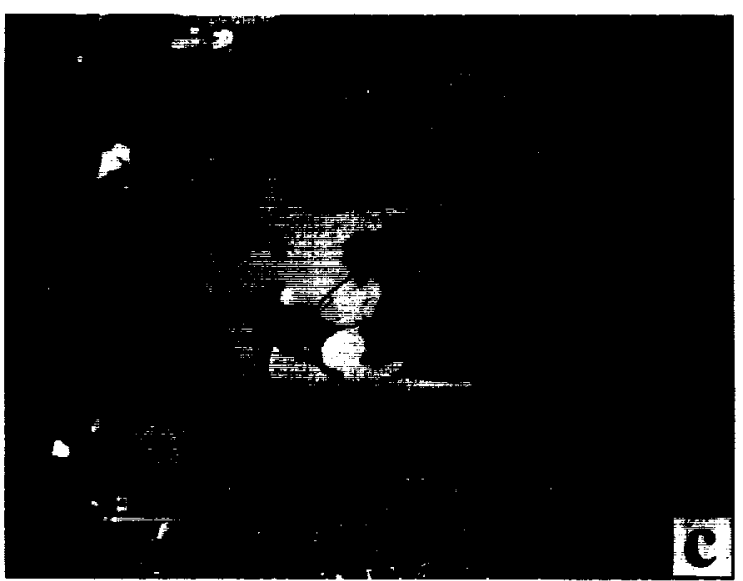

FIG. 2. Backscattered microprobe images of $15474,4,14$ Largest scale bars are $100 \mu \mathrm{m}$. (a) Subhedral/euhedral olivines (bright) and chromites (white) at right and elongate augites (gray) between them and to the right. The bright groundmass phase is mainly pyroxferroite with much less abundant ilmenite. The groundmass also contains augite (gray) and plagioclase and glass (black). The variolitic stucture of the groundmass is apparent and is mainly defined by augite elongation. (b) Largest olivine crystal, containing some chromite (white) and masses of enclosed groundmass that do not contain as much pyroxferroite as typical groundmass. The brightness contrast is different from (a), such that the pyroxferroite in this image is in any case much less bright; the bright groundmass phase is ilmenite. (c) Swallow-tail olivine (pale gray) surrounded by groundmass that is depleted in pyroxferroite, which is the bright phase in the groundmass.

TABLE 2. Neutron activation data for $15474,4,15$.

\begin{tabular}{lcccc}
\hline & $\begin{array}{c}\text { Ol-rich } \\
1.99 \mathrm{mg}\end{array}$ & $\begin{array}{c}\text { G'mass-rich } \\
15.34 \mathrm{mg}\end{array}$ & Bulk,15 & $\begin{array}{c}\text { Estimate of } \\
\text { basalt }\end{array}$ \\
\cline { 1 - 3 } $\mathbf{w t} \%$ & & & & \\
$\mathrm{FeO}$ & 31.6 & 25.7 & 26.3 & 22.5 \\
$\mathrm{Na}_{2} \mathrm{O}$ & 0.03 & 0.31 & 0.28 & 0.38 \\
$\mathrm{~K}_{2} \mathrm{O}$ & $<0.02$ & 0.03 & 0.03 & 0.04 \\
$\mathrm{ppm}$ & & & & \\
$\mathrm{Sc}$ & 10.6 & 38.0 & 34.8 & 44.8 \\
$\mathrm{Cr}$ & 3040 & 3910 & 3810 & 5080 \\
$\mathrm{Co}$ & 155.8 & 83.2 & 91.6 & 55.4 \\
$\mathrm{Ni}$ & 460 & 170 & 203 & 104 \\
$\mathrm{La}$ & 0.76 & 4.36 & $3.95^{*}$ & 5.26 \\
$\mathrm{Ce}$ & & 13.40 & $12.10^{*}$ & 16.11 \\
$\mathrm{Sm}$ & 0.21 & 3.25 & 2.90 & 3.87 \\
$\mathrm{Eu}$ & 0.07 & 0.95 & 0.85 & 1.13 \\
$\mathrm{~Tb}$ & $<0.18$ & 0.83 & $0.75^{*}$ & 1.00 \\
$\mathrm{Yb}$ & $<1.00$ & 2.53 & $2.29^{*}$ & 3.06 \\
$\mathrm{Lu}$ & $<0.12$ & 0.34 & $0.31^{*}$ & 0.41 \\
$\mathrm{Hf}$ & $<0.40$ & 2.20 & $1.99^{*}$ & 2.66 \\
$\mathrm{Ta}$ & $<0.23$ & 0.39 & $0.35^{*}$ & 0.47 \\
$\mathrm{Th}$ & $<0.30$ & 0.40 & $0.36^{*}$ & 0.48 \\
$\mathrm{Sr}$ & & $90^{\ddagger}$ & & \\
\hline
\end{tabular}

* assumes same rare earth element pattern as G'massrich.

$\dagger$ bulk , 15 minus olivine to be consistent with mode and Table 1 analyses.

$\pm \pm 40$ 


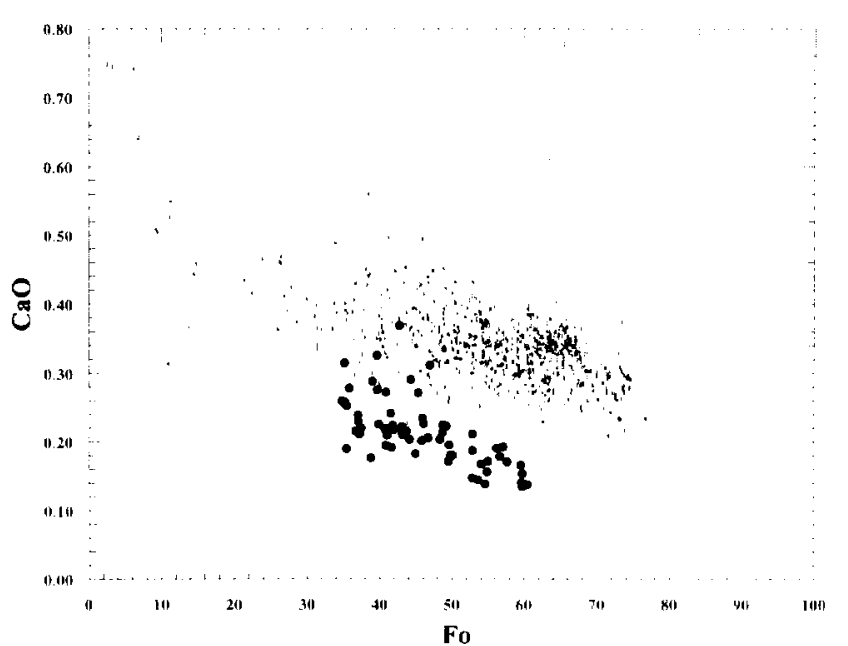

FIG. 3. The $\mathrm{CaO}$ wt $\%$ vs. forsterite content for olivines in $15474,4,14$ (black dots) and in several Apollo 15 olivine-normative mare basalts (other symbols; G. Ryder and B. Schuraytz, unpublished data). The range is more constricted in $15474,4,14$, but most conspicuously, the Ca contents, while still generally in a volcanic range, are lower.

and titania contents (Fig. 5a,b), at the extreme high end of the range exhibited by the most rapidly cooled of the Apollo 15 quartznormative basalts. They also have high $\mathrm{Cr}_{2} \mathrm{O}_{3}$ contents, presumably because little chromite and no magnesian pyroxene crystallized, and so its abundance remained high in the melt. No pyroxenes like these either texturally or chemically have been recognized among any of the Apollo 15 olivine-normative basalts.

The groundmass consists of $\sim 30 \%$ pyroxferroite, $25 \%$ augite, $35 \%$ to $40 \%$ plagioclase, $5 \%$ to $10 \%$ glass, $1 \%$ ilmenite, and traces of Fe-metal. We have not made a study of the chemical composition of these groundmass phases but have confirmed the identities with the microprobe. The metal grains are, in any case, unfortunately too small for microprobe analysis for the potentially informative elements $\mathrm{Ni}$ and $\mathrm{Co}$. The glass is dominantly silica and alumina and occurs as interstitial patches that are mainly $<5 \mu \mathrm{m}$ across. Most mineral grains are anhedral and $<10 \mu \mathrm{m}$ across, but a variolitic or radial texture is partly developed by continuity or elongation of the augite.

The petrography of 15474,4 indicates very rapid cooling. By comparison with observations and crystallization experiments on Apollo 12 olivine basalts (e.g., Donaldson et al., 1975; Walker et al., 1976a,b), qualitatively one can infer from grain sizes and morphologies that the olivines crystallized at at least $10{ }^{\circ} \mathrm{C} / \mathrm{h}$ and the groundmass probably somewhat faster. The high $\mathrm{Ca}$, alumina, and titania contents of pyroxenes are reproduced in experiments at rapid cooling rates, and the abundances are correlated with the amount of supercooling, itself dependent on cooling rates (Donaldson et al., 1975; Walker et al, 1976a,b). The evidence, thus, suggests crystallization either in a flow a few tens of centimeters thick at most or alternatively equally close to the margin of a flow of any thickness. Donaldson et al. (1975) noted that in very rapidly cooled experimental runs, the amount of modal olivine can exceed the normative olivine by as much as $15 \%$. According to the bulk $\mathrm{Mg} /(\mathrm{Mg}+\mathrm{Fc}$ ) (atomic) of the rock (below), the equilibrium olivines crystallized should have been $\sim \mathrm{Fo}_{70}$, yet $\mathrm{Fo}_{60}$ is the most magnesian observed in 15474,4 . This suggests that either the cores re-equilibrated with the melt or that the olivines are

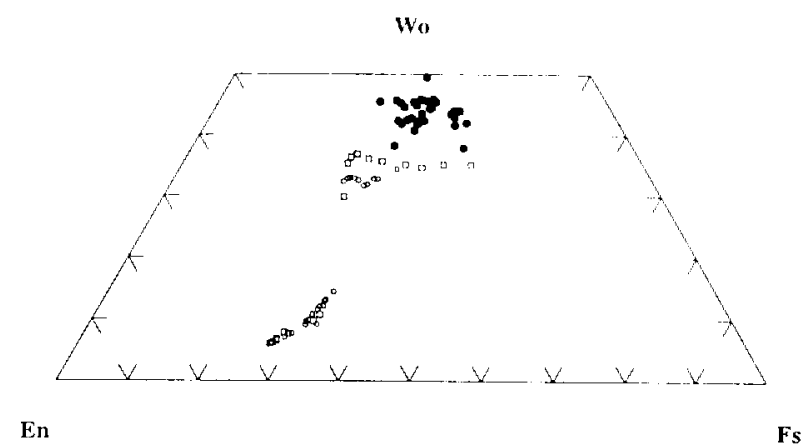

FIG. 4. Pyroxene compositions (calculated from Mg-Fe-Ca data only) for $15474,4,14$ (black dots) and for two samples of rapidly-cooled Apollo 15 quartz-normative basalts: 15125 (open squares) and 15666 (open circles) (Dowty et al, 1973). Sample $15474,4,14$ has pyroxene with significantly higher $\mathrm{Ca}$ abundances and lacks pigeonite, which is unusual for a low-Ti mare basalt.

partly cumulate. Neither explanation is particularly consistent with the rapid cooling, unless the olivines were crystallized prior to eruption. The comparatively low $\mathrm{CaO}$ in the olivines is at least suggestive of this possibility. Not all of the olivine is skeletal, and, hence, is also consistent with accumulation, but all of it is at least mildly zoned.

\section{BULK CHEMICAL COMPOSITION}

Inferences made from the measured chemical compositions (Tables 1 and 2) must be made acknowledging the inherent limitations of the data. All chemical analyses were made on very small samples that may not be representative. The composition for major elements reported by Powell et al. (1973) looks very similar to that of an evolved Apollo 15 olivine-normative basalt, apart from the obvious loss of $\mathrm{Na}$ during fusion of the powder. However, their simultaneous analyses of other recognized Apollo 15 mare groups, including the olivine-normative group, are systematically lower in $\mathrm{FeO}$ and higher in $\mathrm{SiO}_{2}$ than is accepted for those groups. This suggests some analytical bias. The high $\mathrm{SiO}_{2}$ indeed results in the analysis of 15474,4 being slightly quartz-normative, which is unusual for a basalt with $>20 \%$ modal olivine. The major element chemical composition derived from estimating average phase compositions and weighting them according to the mode suffers from the uncertainties in both the mode and the average phase chemical compositions. The groundmass composition was determined by rastering the microprobe electron beam and is reasonably consistent with its mode, except perhaps a little low in $\mathrm{Fe}$ as an artifact of the reduction procedures. Perhaps remarkably, the bulk estimates derived by these methods are similar to the analysis of fused powder, but the $\mathrm{SiO}_{2}$ is a little lower (Table 1). The $22 \%$ to $23 \%$ $\mathrm{FeO}$ derived from the fused bead analysis and the modal reconstructions is fairly typical of Apollo 15 mare basalts. One can conclude that the major clement chemical composition of 15474,4 is probably not greatly different from that of an evolved olivinenormative mare basalt such as 15556 ; it might be a little higher in $\mathrm{Fe}$.

The neutron activation data (Table 2) show that the olivine-rich separate, on the basis of the precisely measured $\mathrm{Na}, \mathrm{Cr}$, and $\mathrm{Sm}$ data in particular, contains $5 \%$ to $10 \%$ groundmass and $\sim 1 \%$ chromite (strangely, this separate has a negative La-Sm slope). If the major 


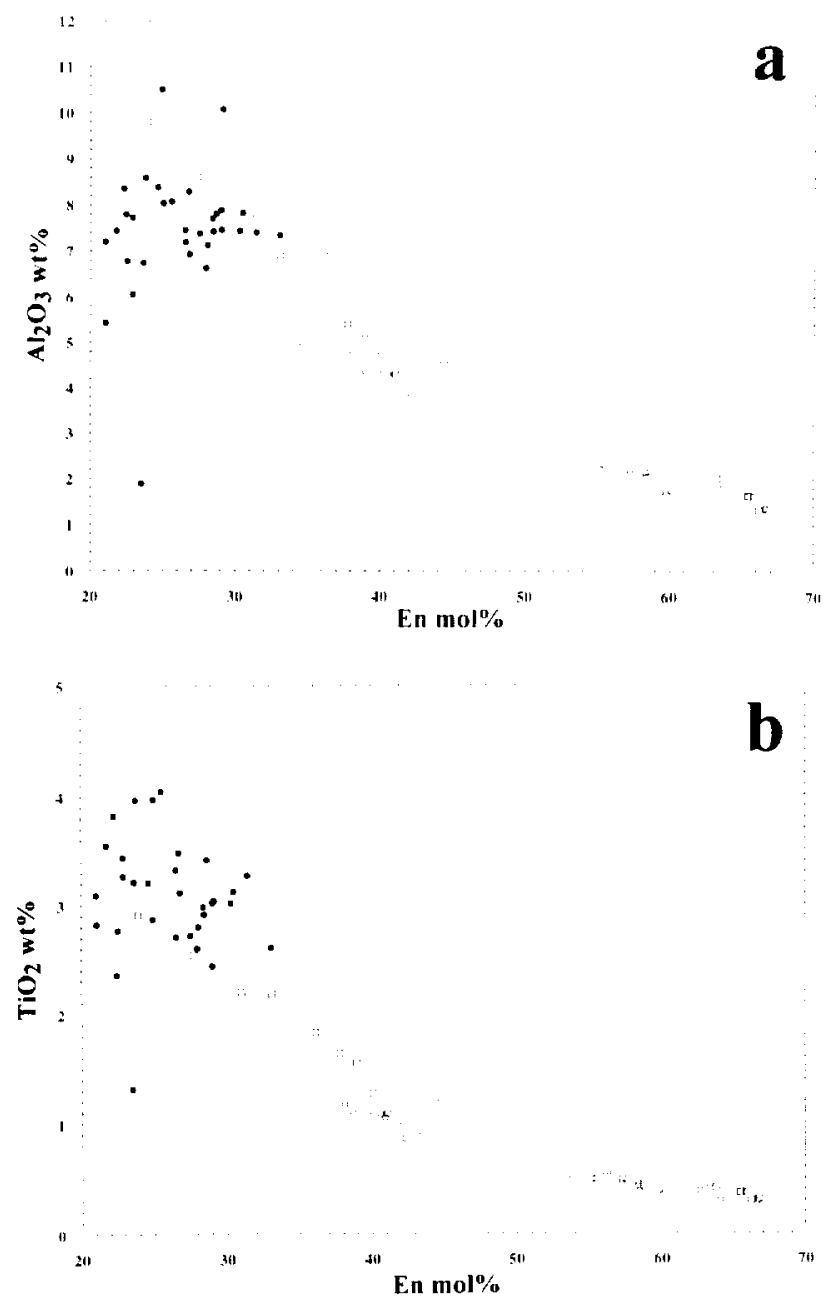

element chemical composition of the rock is reasonably determined by the microprobe analysis (Powell et al, 1973), then even our groundmass sample analyzed by neutron activation must contain excess olivine that is reflected by the higher FeO. However, our combined or total analysis of .15 has $26.3 \% \mathrm{FeO}$, suggesting that the $18 \mathrm{mg}$ subsample is enriched in olivine compared with actual bulk vitrophyre. How much excess olivine depends on what the average olivine composition is $\left(-20 \%\right.$ for $\mathrm{Fo}_{55}$. For many minor elements, the tiny olivine-rich separate provided only upper limits, thus compromising the combined data. Nonetheless, significant limits can be determined. An estimate for the vitrophyre 15474,4, made by subtracting excess olivine from total, 15 , is included in Table 2 (last column).

The rare earth element absolute abundances are very similar to the Apollo 15 olivine-normative and the quart $z$-normative mare basalts, but their relative abundances are slightly different (Figs. 6a, 7) (the combined pattern is not particularly sensitive to the "olivine" pattern). The overall pattern is flatter than for those basalts, and the $\mathrm{Eu}$ anomaly is not quite as great $(\mathrm{Sm} / \mathrm{Eu}=-3.4$ for 15474,4 , compared with more than 3.8 for the others). It is not likely that these differences result from a lack of representativeness: neither groundmass or olivine excess or depletions would influence the rare earth element patterns. An excess of augite in an Apollo 15 olivinenormative composition would flatten the pattern but would not lower the $\mathrm{Sm} /$ Eu ratio.

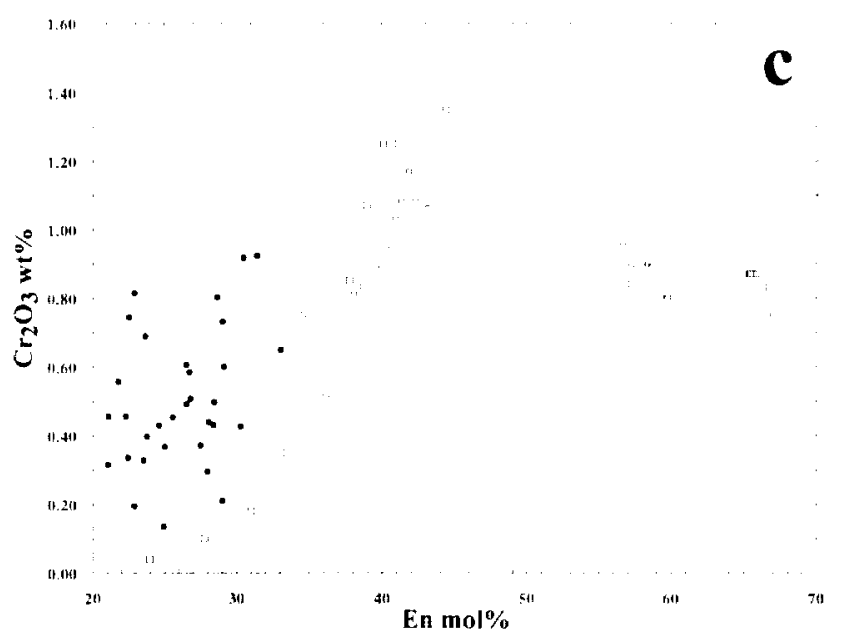

FIG. 5. (a) $\mathrm{Al}_{2} \mathrm{O}_{3}$, (b) $\mathrm{TiO}_{2}$, and (c) $\mathrm{Cr}_{2} \mathrm{O}_{3}$ contents of pyroxenes plotted against their enstatite content, for 15474,4,14 (black dots) and for two samples of rapidly-cooled Apollo 15 quartz-normative basalt 15125 (open squares) and 15666 (open circles) (Dowty et al., 1973). The high contents of $\mathrm{Al}_{2} \mathrm{O}_{3}$ and $\mathrm{TiO}_{2}$ in $15474,4,14$ are conspicuous, as 15125 and 15666 contain among the highest recorded for low- $\mathrm{Ti}$ mare basalts. The high $\mathrm{C}_{2} \mathrm{O}_{3}$ (for the evolved En content) is presumably a result of the low abundance of chromite and lack of Mg-pyroxene into which it might otherwise have been partitioned.

These data indicate not only a general similarity of the rare earth element pattern and abundances with the two main groups of $A$ pollo 15 olivine-normative basalts but also show a general similarity of the pattern with other Apollo 15 mare basalts, including the green glasses, the picritic basalts, the yellow volcanic glass, and that inferred for a local mare basalt represented by a glass sphere of possible impact origin (Ryder et al., 1995). These basalts have a range in $\mathrm{TiO}_{2}$ from $\sim 1 \%$ to $>4 \%$. A sample of coarse-grained feldspathic microgabbro (15388) has a distinct pattern with depleted light rare earth elements and a nonexistent or even positive Eu anomaly, but this sample is probably a cumulate (Ryder and Stecle, 1987). Rare earth element abundances have not been determined on the Apollo 15 red (high-Ti) volcanic glass.

The "Apollo 15" rare earth element pattern is distinct from that of most other lunar basalt types, including the Apollo 1.2 basalts that are also low-Ti basalts (Figs. 6b, 7): most have lower $\mathrm{La} / \mathrm{Yb}$ and $\mathrm{Sm} / \mathrm{Yb}$ ratios. The KREEP basalts and probable KREEPcontaminated samples, such as the Apollo 14 high-alumina basalts, have higher rare earth element abundances, greater Eu anomalies, and higher $\mathrm{La} / \mathrm{Yb}$ ratios (Figs. 6c, 7). Those Apollo 14 highalumina basalts that are less contaminated or uncontanninated have positive overall slopes. The Luna 16 samples have rare earth element patterns (including $\mathrm{Sm} / \mathrm{Eu}$ ) similar to the $\Lambda$ pollo 15 mare basalts but have higher abundances than most (Figs. 6c, 7).

The bulk Sc of $15474,4,15$ is $35 \mathrm{ppm}$; even aczounting for probable excess olivine, the basalt probably does not contain morc than $45 \mathrm{ppm}$ Sc. Thus, it is a low-Sc sample, typical of other Apollo 15 mare basalts and distinct from all other types except the Apollo 12 olivine basalts and the Apollo 17 orange glass. Hubbard and Rhodes (1976) noted that the $A$ pollo 17 orange glass had this characteristic (and others) quite distinct from other $\mathrm{Apolllo} 17$ highTi mare basalts. For 15474,4 , the low $\mathrm{Sc}$ is in association with the typically high $\mathrm{FeO}$ of Apollo 15 mare basalts. On plots of FeO vs. 

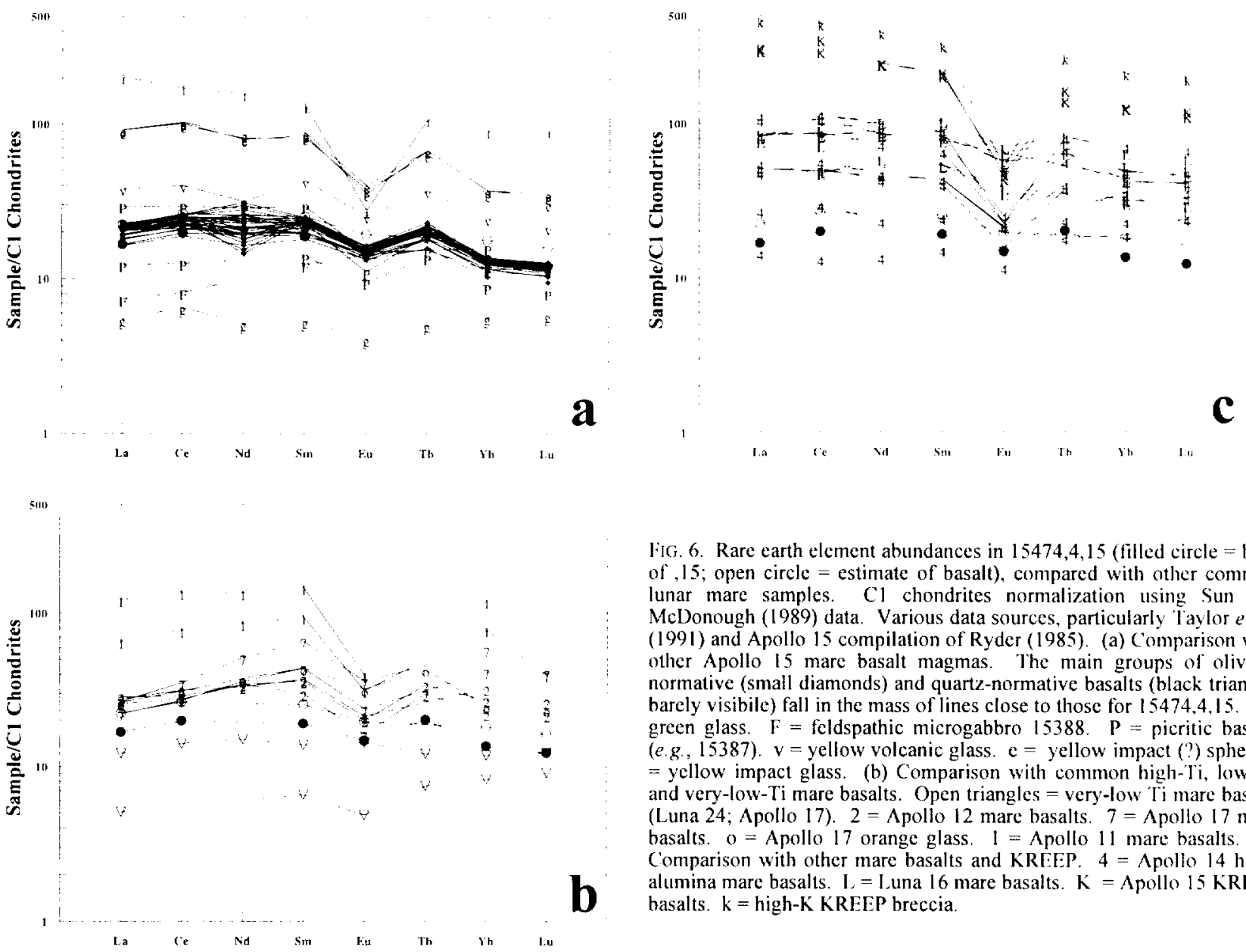

Sc (Fig. 8a) and $\mathrm{TiO}_{2}$ w. Sc (Fig. 8b), 15474,4 falls in a diffuse area with other Apollo 15 mare basalts and is distinct from nearly all other mare basalts. Delano (1990) used $\mathrm{FeO} / \mathrm{Sc}$ ratios to explore relationships among mare magmas; all mare volcanic glasses, not just the $\Lambda$ pollo 17 orange glass, have ratios similar to those of the Apollo 15 basalts and the Apollo 12 olivine basalts. However, it is not apparent in the data presented here that there is such a dichotomy between two mare basalt groupings as in that presented by Delano (1990): instead there appears to be a more nearly continuous range.

The measured bulk Ni (203 ppm) and Co $(92 \mathrm{ppm})$ are higher than that in any other Apollo 15 mare basalt, yet the basalt has a lower $\mathrm{Mg} /(\mathrm{Mg}+\mathrm{Fe})$ (atomic) than others. Although these data might be influenced by an excess of olivine (as nonrepresentative sampling and as cumulate), into which these elements are partitioned, it is nonctheless clear that the bulk 15474,4 contains significant abundances of these elements. These are probably indigenous, although the small size of our sample precluded a check on meteoritic contamination using Ir or Au data in routine analysis. Iron metal is almost absent from the sample, and there is no textural evidence of impact products. The texture is not like any that occurs in sample 15256, a rock that is almost certainly the product of impact melting of Apollo 15 olivine-normative basalt despite the lack of any evidence for meteoritic contamination (Ryder, 1985). The $\mathrm{Ni} / \mathrm{Co}$ ratio of $15474,4,15$ is similar to that of the Apollo 15

JiG. 6. Rare earth element abundances in 15474,4,15 (filled circle $=$ hulk of 15 ; open circle = estimate of basalt). compared with other common lunar mare samples. $\mathrm{C} 1$ chondrites normalization using Sun and McDonough (1989) data. Various data sources, particularly Tavlor et at. (1991) and Apollo 15 compilation of Ryder (1985). (a) Comparison with other Apollo 15 mare basalt magmas. The main groups of olivinenormative (small diamonds) and quartz-normative basalts (black triangle, harely visibile) fall in the mass of lines close to those for $15474,4.15 . \mathrm{g}=$ green glass. $F=$ feldspathic microgabbro $15388 . \quad P=$ picritic basalts (e.g. 15387). $\mathrm{v}=$ yellow volcanic glass. $\mathrm{c}=$ yellow impact (?) sphere $\mathrm{i}$ = ycllow impact glass. (b) Comparison with common high-Ti, low- $\mathrm{Ti}$ and very-low-Ti mare basalts. Open triangles $=$ very-low $\mathrm{Ti}$ mare basalts (Luna $24 ;$ Apollo 17). 2 = $\Lambda$ pollo 12 mare basalts. $7=$ Apollo 17 mare basalts. $0=$ Apollo 17 orange glass. $1=$ Apollo 11 mare basalts. (c) Comparison with other mare basalts and KREEP. $4=\wedge$ pollo 14 highalumina mare basalts. $\mathrm{I}=\mathrm{I}$ una 16 mare basalts. $\mathrm{K}=$ Apollo $15 \mathrm{KREFP}$ basalts. $\mathrm{k}=$ high-K KREEP breccia.

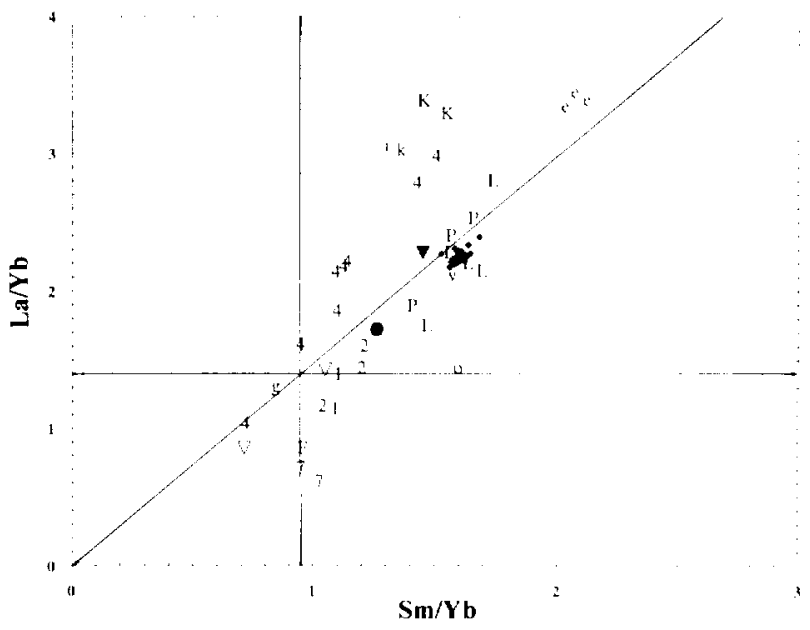

Fig. 7. Ratios of $\mathrm{La} / \mathrm{Yb}$ vs. $\mathrm{Sm} / \mathrm{Yb}$ as an illustration of the slope of the rare earth elements for varied lunar mare samples (symbols as in Fig. 6). Horizontal, vertical, and diagonal lines are the Cl chondritic ratios for $\mathrm{L} \mathrm{a} / \mathrm{Yb}, \mathrm{Sm} / \mathrm{Yb}$, and $\mathrm{La} / \mathrm{Sm}$ respectively. Apollo 14 high-alumina basalts and KREEP form a distinct sequence comparatively enriched in light rare earth elements. Most Apollo 15 mare basalts plot with common slopes both overall and for light rare earth elements. Feldspathic microgabbro 15388 (l) is distinct, but the sample is probably a cumulate. The Apollo 15 green glass also has a much flatter slope. Sample $15474,4,15$ is somewhat flatter than the other Apollo 15 samples but not extremely so, and one picritic basalt sample is similar to it. 

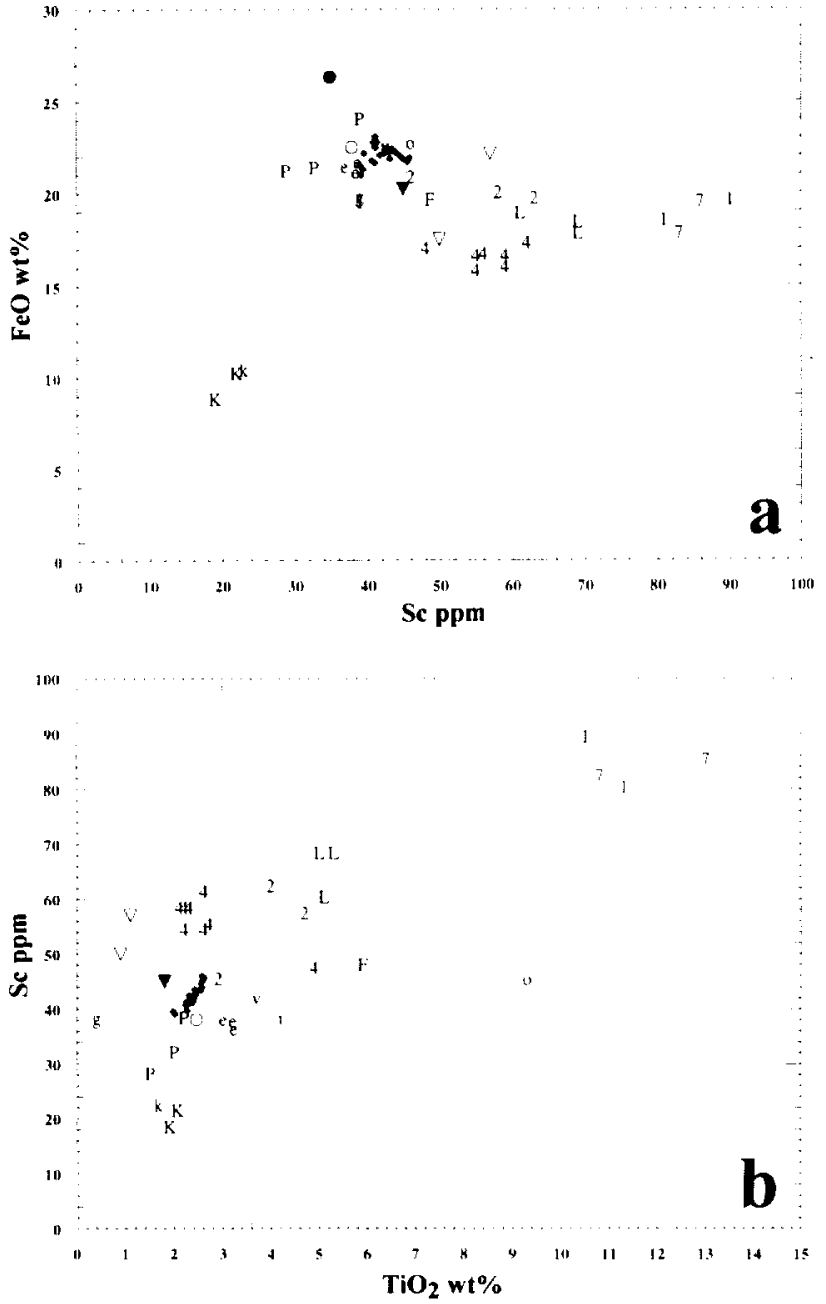

green glasses. If the $\mathrm{Ni}$ and $\mathrm{Co}$ are indigenous, then they demonstrate an origin distinct from the Apollo 15 olivine-normative mare basalts.

The bulk chemical data, like the petrographic and mineral chemical data, indicate that 15474,4 is a distinct mare basalt type and was not created by fractional crystallization at shallow level from one of the other local basalt types. Nor was it likely to have been created by impact melting of one of them. Nonetheless, while in detail it is distinct, its rare earth element pattern, its high $\mathrm{FeO}$, and its low Sc give it affinities with these other Apollo 15 basalts that it does not share with most other sampled lunar mare basalts, including other low-Ti varieties.

\section{AN APOLLO 15 MARE BASALT PROVINCE}

The Apollo 15 mare basalts have similar characteristics of high $\mathrm{FeO}$, low Sc, and reasonably consistent relative rare earth element abundances. They vary in both absolute abundances of $\mathrm{TiO}_{2}$ and rare earth elements (although the two groups most sampled, as well as the picritic group, the feldspathic microgabbro, and 15474,4 described here all have similar rare earth element abundances; Fig. 6a). The $\mathrm{TiO}_{2}$ content among the groups is highly correlated with the rare earth element abundances (Fig. 8c). The chemical similarities among the Apollo 15 basalts, in contrast with the differences between them as a group and most other sampled mare

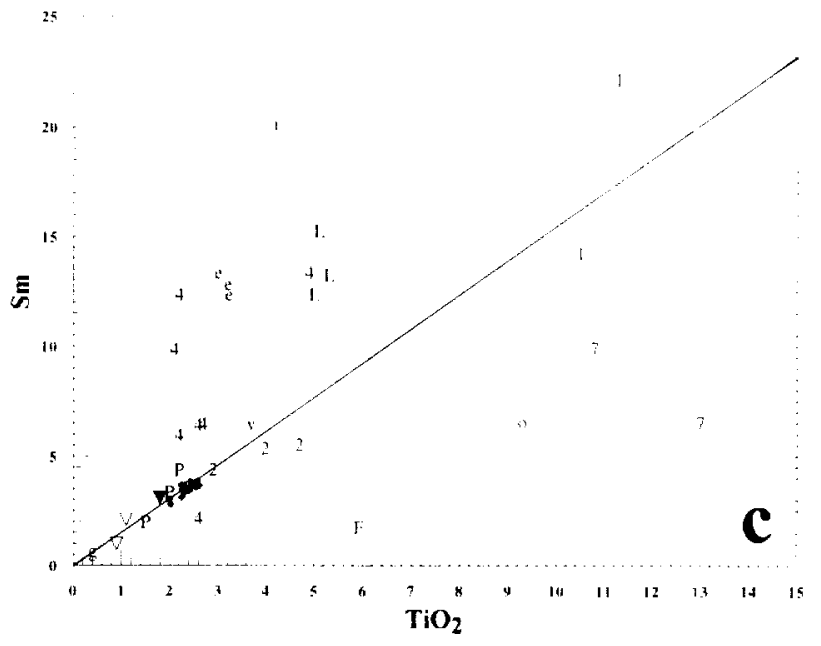

FIG. 8. Element-element scatter plots for 15474,4 and other mare basalts Symbols as in Fig. 6. For 15474,4 basalt, $\mathrm{TiO}_{2}$ and $\mathrm{FeO}$ estimated from modal reconstruction and from fused bead analysis of Powell et al. (1973). (a) $\mathrm{FeO} v s$. Sc. (b) $\mathrm{Sc} v \boldsymbol{s}$. $\mathrm{TiO}_{2}$. (c) $\mathrm{Sm} v \boldsymbol{s}$. $\mathrm{TiO}_{2}$. The 15434,4 symbol is hidden behind cluster of small filled diamonds. The line represents the chondritic ratio.

basalt groups, suggests a common magmatic episode with some similarities of both source and process among them.

Most of the mare basalts collected at the Apollo 15 landing site appear to have been extruded over a short period of time, from $\sim 3.15 \mathrm{Ga}$ to $3.35 \mathrm{Ga}$ (Nyquist and Shih, 1992, recalculated ages using decay constants of Steiger and Jager, 1977). These include the olivine-normative and quartz-normative groups, the picritic basalts, the feldspathic microgabbro, and the green glass. The yellow volcanic glass is slightly, but significantly, older at $3.62 \mathrm{Ga}$ (Spangler et al., 1984). Sample 15474,4, described here, and the red volcanic glass are as yet undated. The common Apollo 15 yellow impact glass has an age of $3.35 \mathrm{Ga}$ (Spangler and Delano, 1984), a lower limit to the age of the mare basalt source, and the distinct yellow impact (?) glass sphere has an age of $1.65 \mathrm{Ga}$ (Ryder et al., 1995).

The Apollo 15 mare basalts cluster on a plot of $\mathrm{I}(\mathrm{Sr})$ vs. I(Nd), partly overlapping the looser cluster of Apollo 12 basalts (Nyquist and Shih, 1992). The range in $\mathrm{I}(\mathrm{Sr})$ among Apollo 15 basalts is a little greater than analytical uncertainty, with the picritic basalt being slightly younger and having higher $\mathrm{I}(\mathrm{Sr})$ than the feldspathic microgabbro. The Apollo 15 and Apollo 12 basalts are distinguished clearly in the lower $\epsilon \mathrm{Nd}$ of the clustered Apollo 15 mare basalts, except for the feldspathic microgabbro which has a higher $\epsilon \mathrm{Nd}$, closer to that of the Apollo 12 basalts.

The Apollo 15 basalts, on the basis of their similarities in chemical composition and isotopic characteristics and, in general, their ages, can be considered a single chemical province. Their similarities can be used to infer some commonalities among their sources, the origin of those sources, and the melting processes that produced the basalts. Their differences can be used to infer some differences among those features. Most workers have stressed the differences and the implications for mantle heterogeneity at a single site (e.g., Nyquist et al., 1977, 1979; Neal and Taylor, 1992), rather than stressing what the commonalities might mean. For instance, many workers have stressed the "primitiveness" of the Apollo 15 
green glass, even suggesting a deeper unfractionated, or little fractionated, source in substantial contrast with the sources of the main Apollo 15 basalts. Yet the green glasses have the same $\mathrm{FeO} / \mathrm{Sc}$ characteristics as these other basalts and are different from most basalts at other sites. It seems reasonable to suppose that more information can be gathered by an integrated approach than by considering each basalt group in isolation.

\section{The Iron Oxide/Scandium Ratio}

The high $\mathrm{FeO} / \mathrm{Sc}$ ratio, a result of both high $\mathrm{FeO}$ and low $\mathrm{Sc}$, is a significant and distinguishing characteristic of the $A$ pollo 15 basalts (Fig. 8a). Only the Apollo 12 olivine basalts and the $\Lambda$ pollo 17 orange glass have this same characteristic (although Delano, 1990, claims that the Luna 24 very low-Ti basalts have it too). The similarity among the $\Lambda$ pollo 15 mare basalts demands some commonality of source or melting processes or both. Assuming a general model of source production that includes cumulates from a magma ocean, and subsequent remelting and extrusion to produce a basalt, then the FeO and $\mathrm{Sc}$ abundances in the basalt will be influenced potentially by several factors. These include their abundances in the magma ocean during source production, the modal mineralogy of the cumulate source, trapped magma, the proportions of the minerals consumed during partial melting (which can depend on depth of melting as the olivine-pyroxene cotectic shifts), the amount of partial melting, assimilation, and fractional crystallization during ascent and flow. Calculations using reasonable partition coefficients (e.g., as used by Snyder et al., 1992) show that at least for reasonable degrees of partial melting $(<-20 \%)$ and where neither olivine nor pyroxene is totally consumed, the amount of Sc in the melt for a given source varies by $<10 \%$ whatever the amount of partial melting, cumulate mineral proportion, trapped liquid, or cotectic melt proportion. (A $10 \%$ increase in Sc can be obtained by separating $-15 \%$ olivine after the melt has been formed because $\mathrm{Sc}$ is incompatible in olivine; this happened in the shallow crystallization of the Apollo 15 olivinenormative basalts.) In contrast, the $\mathrm{Sc}$ in the melt is directly sensitive to the $\mathrm{Sc}$ in the phases in the source, which in turn is dependent on the composition of the ocean magma at the time of cumulate formation (or, if the source is a mix from overturning or some such process, on the average of that mix). Delano (1990), inferring reasonably that bulk partition coefficients for $\mathrm{FoO}$ and $\mathrm{Sc}$ during partial melting were about unity, deduced that the observed differences (particularly the dichotomy) among $\mathrm{FeO} / \mathrm{Sc}$ ratios were inherited from the mantle sources.

The FeO varies with the amount of partial melting but not by much because the $\mathrm{FeO}$ in the melt and in the equilibrium olivine are very similar. As with $\mathrm{Sc}$, the $\mathrm{FeO}$ of the source phases (hence, source origin) is the dominant influence. With very large amounts of partial melting, the $\mathrm{FeO}, \mathrm{Sc}$, and, thus, $\mathrm{FeO} / \mathrm{Sc}$ ratios must approach those of the bulk source, and this ratio is strongly dependent on the cumulate phase ratio; olivine-rich sources will have much less total $S c$ than pyroxene-rich sources. The implication of this consistency of $\mathrm{FeO} / \mathrm{Sc}$ in the $\Lambda$ pollo 15 mare basalts is that most of them (olivine-normative; quartz-normative; picritic; 15474,4; green glass; yellow volcanic glass; yellow impact glass terrain; yellow impact sphere terrain) formed from reasonably low degrees of molting of sources that had very similar major silicate phase compositions (hence, probable common origin), and that this was different from the source of most other lunar mare basalts so far sampled. There might be some difficulty in reconciling such an inference with models that require very different sources, including primitive ones and those at very different depths.

\section{Absolute and Relative Rare Earth Element Abundances}

The absolute and relative rare earth element abundances in a melt from a given source are little influenced by the position of the cotectic. However, the absolute abundances are strongly influenced by the degree of partial melting. The relative abundances are strongly influenced by any magma originally trapped in the cumulate, by the degree of partial melting, and by the phase proportions of the cumulate. The reasonable consistency of the Apollo 15 basalt pattern, yet great variation in overall abundance, can perhaps be attributed to variation in the abundance of a common trapped liquid within the otherwise homogeneous silicate cumulates. If the relative abundance variations were the result of varied amounts of partial melting, then there should be larger variations in the relative abundances (even given an otherwise common source) than are generally the case. Large variations in the cumulate phase proportions would also have a noticeable effect if there were not a trapped magma effect.

\section{The Titanium Oxide/Samarium Ratio}

The Apollo 15 mare basalts have a common $\mathrm{TiO}_{2} / \mathrm{Sm}$ ratio (Fig. $8 \mathrm{c})$ over a substantial range of $\mathrm{TiO}_{2}$. This ratio is, within uncertainty, the chondritic ratio and presumably that of the bulk Moon. The magma that was trapped in the cumulate sources did not suffer from $\mathrm{TiO}_{2}$ depletion (relative to other incompatible elements), such as is the case for KREEP basalts. (The Apollo 14 mare basalts and the Apollo 15 impact glasses that may have assimilated KREEP, have subchondritic $\mathrm{TiO}_{2} / \mathrm{Sm}$.) Nor did it undergo relative $\mathrm{TiO}_{2}$ enrichment as is the case for at least some high-Ti mare basalts. Thus, any trapped magma must have been a reasonably contemporaneous ocean magma, not an evolved, residual one. (However, Longhi, 1992, noted a slightly super-chondritic $\mathrm{Ti} / \mathrm{Sm}$ ratio for Apollo 15 olivine-normative mare basalts and that their ratio of the more incompatible elements $\mathrm{Nb} / \mathrm{La}$ was distinctly higher than chondritic, requiring the presence of evolved material in some form.) It might be expected that with $\mathrm{TiO}_{2}$ in pyroxenes in the source, there would have been some variation in $\mathrm{TiO}_{2} / \mathrm{Sm}$ with variation of partial melting and with cumulate phase proportion. The $\mathrm{TiO}_{2} / \mathrm{Sm}$ consistency is most easily reconciled by invoking small and consistent degrees of partial melting; different amounts of a similar trapped magma for the sources of different basalts; an olivine-rich source rather than a pyroxene-rich one; and particularly an incompatibility of Ti even for pyroxene.

\section{Radiogenic Isotopes}

Those Apollo 15 mare basalts analyzed have $\mathrm{Sr}-$ and $\mathrm{Nd}-$ isotopic characteristics more similar to each other than to other basalts (see Nyquist and Shih, 1992). They are slightly distinguished from Apollo 12 mare basalts on $\mathrm{I}(\mathrm{Nd})$ and completely distinguished from them on the basis of $\epsilon \mathrm{Nd}$. The isotopic data are inconsistent with assimilation or interaction with KREEP or granitic materials by the Apollo 15 magmas (as is also indicated by the $\mathrm{TiO}_{2} / \mathrm{Sm}$ relationship). The $\epsilon \mathrm{Nd}$ data show little departure from a chondritic or bulk-Moon evolution of the source prior to eruption, consistent with trapping of contemporaneous magma ocean during source formation. The radiogenic isotope data are thus consistent with a commonality among Apollo 15 mare basalts in their sources that is distinct from those of all other mare basalts. Unravelling the 
precise nature of the relationships among the rare earth element ahundances, radiogenic isotopes, trapped magma, and cumulate phases requires considerably more study.

\section{CONCLUSIONS}

$A$ distinct type of mare basalt from the Apollo 15 landing site. so far represented by only a tiny fragment. 15474,4, is nonetheless part of a chemical province that incorporates most of the Apollo 15 mare basalts. The fragment is an olivine-augite vitrophyre that crystallized rapidly in a thin flow or near the edge of a flow. It has more olivine $(22 \%)$ than almost all other lunar mare basalts. Its high $\mathrm{FeO} / \mathrm{Sc}$ ratio, its relative rare earth element abundances, and its $\mathrm{TiO}_{2} / \mathrm{Sm}$ ratio group it clearly with Apollo 15 olivine-normative basalts, quartz-normative basalts, green and yellow volcanic glasses, and picritic basalts. While most authors have emphasized the differences among mare basalt sources, including differences among those for the Apollo 15 mare basalts, the commonality of chemical characters demands some commonality among Apollo 15 mare basalt sources and melting processes that is distinct from the sources and processes elsewhere. Most of these Apollo 15 magmas were extruded within $200 \mathrm{Ga}$ of each other. By considering the Apollo 15 mare basalts as a related group, rather than as isolated basalts, one can make reasonable inferences that are mutually consistent and not coincidental. One is that the Apollo 15 basalts were derived by melting of sources that had common major phase compositions, at least in $\mathrm{FeO} / \mathrm{Sc}$, and. thus, some common relationship that might derive from a magma ocean. It perhaps follows that melting at widely different depths to produce the basalts is not particularly plausible. Further, only a limited amount of olivine separation after melt production is consistent with the $\mathrm{FeO} / \mathrm{Sc}$ data. The variation in absolute rare earth element abundances and $\mathrm{TiO}_{2}$, the limited variation in relative rare earth element abundances, and the nearchondritic and constant $\mathrm{TiO}_{2} / \mathrm{Sm}$ ratio are most consistently understood as a result of varied trapping of magma ocean within the cumulates, small and reasonably consistent amounts of partial melting, and a high ratio of olivine to pyroxene $(>3$ to 1 ). The radiogenic Sr- and Nd-isotopic data are probably consistent with such an origin for the basalts.

The Apollo 15 mare basalts show some chemical commonalities; the inferences for lunar evolution that might be obtained from them have generally been neglected and an emphasis placed on the differences among them. These differences are indeed real and reveal important information about the Moon. However, an integrated approach would be advantageous. In this paper, we have not tried to do more than illustrate the point. Many features require elucidation. including understanding the details of the rare earth clement differences. the $\mathrm{Sm} / \mathrm{Lu}$ variations, and the $\mathrm{Mg} /(\mathrm{Mg}+\mathrm{Fe})$ differences. Data from other landing sites demonstrates that the Apollo 15 landing site is not unique in being a chemical province: there are surely commonalitics among at least some of the $\Lambda$ pollo 12 basalts and among the $A$ pollo 17 basalts. The study of these provinces as such rather than as collections of isolated basalts and the incorporation of the inferences made from them for physical models of source formation and subsequent magma production and extrusion offers advances in our understanding of the Moon.

In general, $\mathrm{TiO}_{2}$ content has been used as a major classification parameter. However, the $\Lambda$ pollo 15 mare basalts have a commonality that reaches over a substantial range in $\mathrm{TiO}_{2}$. Furthermore, the correlation of $\mathrm{TiO}_{2}$ with $\mathrm{Sm}$ means that subdividing Apollo 15 basalts by the former is equivalent to subdividing them by the latter.
It may be that other characteristics, such as the $\mathrm{FeO} / \mathrm{Sc}$ ratio (Delano 1990). offer a more meaningful way to classify lunar mare basalts, but at present the petrogenetic framework is inadequate to decide. The present study shows that the search for undescribed (or incompletely described) basalt types, whether in the existing collection, in Antarctica, or in future mission collections, is a significant activity. Single types can add greatly to our knowledge when incorporated into the constraints on an entire province.

Acknowledgements-We appreciate Rene Martinez., David Mittelfehldt, and Vincent Yang of Lockheed for their assistance in the neutron activation and microprobe analyses at the Johnson Space Center. Reviews by Gary Lofgren and John Longhi helped clarify some aspects of mare basalts neglected by the authors, and we appreciate their help and that of the the Associate Editor, Paul Warren. This work was done with support for the NASA Planetary Materials and Geochemistry Program. The Lunar and Planetary Institute is operated by the Universities Space Research Association under contract NASW-4066 with the National Aeronautics and Space Administration. This paper is Lunar and Planetary Institute Contribution 866

Editorial handling: P. Warren

\section{REFERENCES}

BVSP (1981) Basaltic Volcanism on the Terrestrial Planets. Pergamon, New York. 1286 pp.

DII.ANO J. W. (1990) Pristine mare glasses and mare basalts: Evidence for a general dichotomy of source regions. In Workshop on Lunar Volcanic Glasses: Scientific and Resource Potential (eds. J. W. Delano and G. II. Heiken), pp. 30-31. I.PI Tech. Rept. 90-02.

DONALDSON C. H., USSELMAN 'T. M., WILl.IAMS R. J. AND L.ofgren G. E. (1975) Experimental modelling of the cooling history of Apollo 12 olivine basalts. Proc. Lunar Sci Conf. 6th, 843-869.

Dowty E., Prinz M., Neiru C. E., Morlland G., Moori: R. B., Kell K., HI.AVA P. F. AND GREEN J. A. (1973) Electron Microprohe Analyses of Minerals from Apollo 15 Mare Basalt Rake Samples. Univ. New Mexico Inst. Meteoritics Spec. Pub. 9. $113 \mathrm{pp}$.

HEAD J. W. AND WILSON L. (1992) Lunar mare volcanism: Stratigraphy, eruption conditions, and the evolution of secondary crusts. Geochim. Cosmochim. Acta 56,2155-2175

llubBard N. J. AND MiNeAR J. W. (1975) A physical and chemical model of early lunar history. Proc. Lunar Sci. Conf 6th, 1057-1085

IIUBBARD N. J. AND RHODES J. M. (1976) The chemical composition of Apollo 17 orange glass (abstract). Lumar Sci. 7, 390-392.

KoEBERL C., KURAT G. AND BRANDSTATTER F. (1993) (iabbroic lunat mare meteorites Asuka-881757 (Asuka-31) and Yamato-793169: Geochemical and mincralogical study. Proc. NIPR Symp. Antarct. Meteorites 6th, 14-34.

LONGHI J. (1992) Experimental petrology and petrogenesis of mare volcanics. Geochim. Cosmochim. Acta 56, 2235-2251

NEAL C. R. AND TAYlor L. A. (1992) Petrogenesis of mare basalts: $\wedge$ record of lunar volcanism. Geochim. Cosmochim. Acta 56, 2177-2211.

NYQUisT L. E. AND SHII C.-Y. (1992) On the chronology and isotopic record of lunar basaltic volcanism. Geochim. Cosmochim. Acta 56, 2213-2234

Nyouist L. E., BAnsal. B. M., WOOdEN J. I, AND WIESManN II. (1977) Srisotopic constraints on the petrogenesis of Apollo 12 mare basalts. Proc. Limar Sci. Conf. 8th, 1383-1415.

NYquiST L. E., SHIH C.-Y., WOODEN J. L, BANSAL B. M. AvD WIESMANN H. (1979) The $\mathrm{Sr}$ and $\mathrm{Nd}$ isotopic record of Apollo 12 basalts: Implications for lunar geochemical evolution. Proc. Lunar Planet. Sci. Conf 10th, 77-114.

PAPIKE J. J., Hodges F. N., Bence A. E., CAMERON M. ANI RIIOdes J. M. (1976) Mare basalts: Crystal chemistry, mineralogy, and petrology Rev. Geophys. Space Phys. 14, 475-540.

POWELL B. N. (1972) Apollo is Coarse Fines $(410 \mathrm{~mm})$ : Sample Classification, Description, and Inventory. NASA-MSC 03228. $91 \mathrm{pp}$.

POWELl B. N., AITKEN F. K. AND WEIBLEN P. W. (1973) Classification, distribution, and origin of lithic fragments from the Hadley-Apennine region. Proc. Lunar Sci. Conf. 4th, 445-460.

RINGWOOD A. E. AND KESSON S. E. (1976) $\wedge$ dynamic model for mare basalt petrogenesis. Proc. Iunar Sci. Conf. 7th, 1697-1722.

RYDER G. (1985) Catalog of Apollo 15 Rocks. Curatorial Branch Publication 72, JSC 20787. $1296 \mathrm{pp}$.

Ryder G. AND Sherman S. B. (1989) The Apollo 15 Coare fines $(4-10$ 
mm) NASA-JSC 24035, SSED Planctary Science Branch Pub. 81. $207 \mathrm{pp}$.

RYDER G AND STEFIF A (1987) (hemical dispersion among Apollo 15 olivine-normative mare basalts. Proc. Lunar Planet. Sci Conf. 18th, $273-282$.

RYDER (i. DI:LANO J W. WARREN P. H, KAlIIMAEYN (j. W MND DAIRYMPLE (j. B. (1995) $\wedge$ glass spherute of equivocal impact origin from the $A$ pollo 15 landing site: Unique target mare basalt. Geochim. Cosmochim Acta, in press.

SNyder G A. TAYior I. A AND NEA. C. (1992) A chemical model for generating the sources of mare hasalts: Combined equilibrium and fractional crystallization of the lunar magmasphere. (ieochim. Cosmochim. Acta 56, 3809-3823.

SPANGiLER R. R. AND DIIANO J. W. (1984) Ilistory of the Apolo 15 yellow impact glass and sample 15426 and 15427. Proc: Lanar Plonet. Sco Conf. 14th, J. Geophys Res. 89, 13478-13486.

SPANGIIR R. R.. WARASHA R. ANI DLLANO J. W. (1984) ${ }^{39}$ Ar- ${ }^{40}$ Ar ages for the Apollo 15 green and yellow volcanic glasses. Proc. Lanar

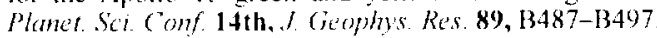

SPERA F. (1992) I unar magma transport phenomena Geochim. Cosmochim. Acta 56, 2253-2265.

STFiger R. 11. AND JAGikR I: (1977) Subcommission on Geochronology:
Convention on the use of decay constants in Geo- and C'osmochronology. Earth Planet. Sci Lett 36, 359-362.

SUIN S. S. AND MCDONOUCiH W. F. (1989) Chemical and isotopic systematics of oceanic hasalts: Implications for mantle composition and processes. In Magmatism in the Ocean Basins (eds. A. D. Saunders and M. J. Norry), pp. 313-345. Geol. Soc l Iondon, Spec. Pap. 42.

TAYLOR $G$ I W WRREN P. RYDER (i. DHLANO J. PIFTERS C. ANI LOFGREN G. (1991) Iunar Rocks. In Lunar Sourcebook (eds. G. H. Heiken, D. T. Vaniman and B. M. French), pp. 183-284. Cambridge Univ. Press, Cambridge

TAYloR S. R. (1982) Planetary Science: A Lunar Perspective. I unar and Planctary Institute, Houston. Texas. $512 \mathrm{pp}$.

WALKER D. I.ONGHI J, KIRKPATRICK R. J. AND HAYS J. F. (1976a) Differentiation of an Apollo 12 picrite magma. Proc. Limur Sci. Conf. 7ih, $1365-1389$

WALKER D. KIRKPATRICK R. J., LONGH J. AND HAYS J. F, (1976b) Crystallization history of lunar picritic basalt sample 12002: Phase equilibria and cooling rate studies. Bull Geol $S_{0 c}$ Am. 87, 646-656.

WARRIN P. H. AND KALLMEYN (j. W. (1993) Genchemical investigation of two lunar mare meteorites: Yamato-793169 and Asuka-881757. Proc NIPR Symp Antarct Meteorites 6th. 35-57. 


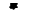

